\title{
Demonstrating the relationship between the phytochemical profile of different teas with relative antioxidant and anti-inflammatory capacities
}

\author{
Xiu-Min Chen, Zhili Ma, and David D Kitts*
}

Food, Nutrition, and Health, The University of British Columbia, 2205 East Mall, Vancouver, Canada

*Corresponding Author: David D. Kitts, PhD, Food, Nutrition, and Health, The University of British Columbia, 2205 East Mall, Vancouver, Canada

Submission Date: February $28^{\text {th }}$, 2017, Acceptance Date: May 26 ${ }^{\text {th }}$, 2017, Publication Date: June $30^{\text {th }} 2017$

Citation: Chen X.M., Ma Z., and Kitts D.D.. Demonstrating the relationship between the phytochemical profile of different teas with relative antioxidant and anti-inflammatory capacities. Functional Foods in Health and Disease 2017; 7(6); 375-395.

https://doi.org/10.31989/ffhd.v7i6.342

\begin{abstract}
Background: Indigenous or traditional aqueous plant extracts are commonly used by nearly $80 \%$ of the world's population for primary health needs. Accordingly, teas such as Camellia sinensis and herbal teas were characterized for their phytochemical content and potential to offer specific bioactivities that could benefit human health by mitigating oxidative stress and inflammation.
\end{abstract}

Methods: In the present study, we compared the phytochemical profiles, antioxidant, and antiinflammatory activities of four Camellia sinensis teas, including white, green, oolong, black, and two herbal teas. These two herbal teas, Rooibos and Yerba mate, are produced and consumed by different populations worldwide. We also studied the impact of the Rooibos tea on the production of inflammatory mediators, including nitric oxide (NO), inducible nitric oxide synthase (iNOS), cyclooxygenase 2 (COX-2), and different cytokines in Raw 264.7 cells, both with or without interferon $\gamma($ IFN- $\gamma)$ and lipopolysaccharide (LPS) stimulation.

Results: White tea had the highest total phenolic content (TPC) and antioxidant activity among the six teas that were examined. In contrast, Rooibos tea had the lowest TPC, antioxidant, and antiinflammatory activities. Yerba mate tea exhibited the greatest potential to inhibit NO production in IFN- $\gamma$ and LPS-induced Raw 264.7 cells. The anti-inflammatory activity of teas was discovered to be correlated with antioxidant activity and phytochemical composition. Among the six teas examined, only Rooibos tea was found to induce NO in unstimulated Raw 264.7 cells. Under basal conditions, Rooibos tea induced interleukin-1 $\alpha$ (IL-1 $\alpha$ ), IL-1 $\beta$, IL-6, IL-10, granulocyte-colony 
stimulating factor (G-CSF), granulocyte macrophage colony-stimulating factor (GM-CSF), tumor necrosis factor-alpha (TNF- $\alpha$ ), iNOS, and COX-2 production. However, Rooibos tea also demonstrated a dose-dependent inhibition of IL-6, IL-10, iNOS, and COX-2 expression in stimulated Raw 264.7 cells. Although a high concentration of Rooibos tea was effective in inhibiting induced IL-1 $\alpha$, G-CSF, and GM-CSF, lower concentrations also up-regulated the expression of these cytokines. No inhibitory effects of Rooibos tea examined were discovered with the mitigation of IL- $1 \beta$ and TNF- $\alpha$.

Conclusion: Rooibos tea possesses dual functions on inflammation, either by promoting an inflammatory response to cytokine induction or alternatively inhibiting inflammation during tissue injury or a pathogen infection via a mechanism involving the inhibition of pro-inflammatory cytokines and mediators such as iNOS and COX-2. The potential of Rooibos tea to induce NO production is also noteworthy in mitigating disease states including hypertension and cardiovascular diseases.

Keywords: Camellia sinensis, Rooibos tea, herbal tea, inflammation, cytokine, antioxidant

\section{INTRODUCTION}

Tea are the second most popular beverage worldwide. Part of the appeal of teas including Camellia sinensis and herbal teas are their supposed health benefits. White, green, oolong, and black teas are distinct types of teas produced from the young leaves of Camellia sinensis tree using specific processing methods. White tea is an unfermented tea that is the least processed and rarest type of tea. White tea is simply produced by withering and drying the young spring buds and immature leaves in the sun [1]. Green tea is also an unfermented tea produced by withering, steaming, or pan frying, processes that are followed by drying to minimize chemical and enzymatic reactions [2]. In the production of semi-fermented oolong tea, tea leaves undergo withering, panning, rolling, and drying [2]. During the processing of fermented black tea, the withered leaves are macerated using orthodox methods (rolling, stretching, and tearing), or unorthodox orthodox methods (e.g. curling, tearing, and crushing) to accelerate the oxidation of catechins into products of theaflavines and thearubigins by polyphenol oxidase [2]. Consumers across the globe have varying preferences when it comes to tea. For example, black tea makes up about 76-78\% of the world's tea production, being primarily consumed in North American, Europe, and North Africa. On the other hand, around $20-22 \%$ of tea produced is green tea, which is mainly consumed in East and South East Asia. Less than $2 \%$ of oolong tea is consumed, being more popular in China $[3,4]$. White tea, which is the rarest of all teas, is mainly produced and consumed in China. The major bioactive compounds in Camellia sinensis teas are catechins, including epigallocatechin-3-gallate (EGCG), epicatechin-3-gallate (ECG), epigallocatechin (EGC), and epicatechin (EC) [5]. Camellia sinensis teas have been recognized as excellent beverages that are sources of dietary antioxidants with protective capacities to protect or mitigate various disease states including cardiovascular disease, cancer, gastrointestinal diseases, arthritis, allergies, diabetes, dental caries, and inflammation [6].

Yerba mate (Ilex paraguariensis) tea is a herbal tea originally consumed by native Guaranies in South American countries as a psychostimulant. This tea is a popular non-alcoholic beverage in South America which has become more well-known in the United States and Europe [7]. In recent 
years, considerable scientific interest has been directed at the medicinal potential of this tea, including antioxidant activities as well as some involvement in vasodialation, hypolipidemia, obesity, and anti-inflammation [8-10]. Yerba mate tea contains large amount of chlorogenic acids and caffeine followed by purine alkaloids and flavonoids, including quercetin, kaempferol, and rutin. The processing procedures for Yerba mate tea include blanching, drying, and aging of the tea [9]. During blanching, the mate tea leaves are flash heated over an open flame to deactivate polyphenol oxidase, which inhibits fermentation [9].

Rooibos (Aspalathus linearis) tea is a caffeine-free herbal tea that originated from South Africa that is now consumed worldwide. Rooibos tea is rich with dihydrochalcones, aspalathin, nothofagin, and quercetin, traditionally being used for its therapeutic properties due to antioxidant, anti-mutagenic, anti-carcinogenic, anti-inflammatory, anti-viral, and anti-diabetic activities [1114]. In traditional processing, the green needle-like leaves and stems are shredded into 3-4 mm length and then left to ferment for 8-24 h before sun-drying in order to produce a red color, a shade called Rooibos [15]. During fermentation, aspalathin undergoes cyclization to produce flavanones dihydro-orientin and dihydro-iso-orientin [16]. The fermented Rooibos tea has been a major product in the tea market since 1904, while a new product made of green Rooibos is now also attracting public interest.

Inflammation is the response of tissue to injury or induced by the invasion of microorganisms, and can be defined as either an acute or chronic condition. Both acute and chronic inflammatory responses are mediated by four groups of mediators, two of which are nitric oxide (NO) and cytokines such as interleukins (IL), tumor necrosis factor (TNF), granulocyte-colony stimulating factor (G-CSF), and granulocyte macrophage colony-stimulating factor (GM-CSF) [17]. Inducible enzymes including cyclooxygenase $2(\mathrm{COX}-2)$ and inducible nitric oxide synthase (iNOS) are also stimulated with an inflammatory response, with both of them inducing various pro-inflammatory cytokines production. The upregulation of iNOS expression causes the excessive production of NO during inflammation that results in oxidative stress, an underlying cause for chronic disease conditions including cancer and inflammatory bowel diseases [18]. However, under physiological conditions, endogenous NO acts as a vasodilator to regulate blood pressure [19].

Plants or plant-derived formulations continue to be used as a treatment for disorders that relate to inflammation, a practice developed from ancient tradition [20]. Although there has been significant reporting on the antioxidant activities of teas, there is less information on the comparison of the anti-inflammatory activities of different teas relative to both phytochemical composition. In the present study, we compared the phytochemical profiles of six different teas and characterized relative capacities for both antioxidant and anti-inflammatory activities. There was emphasis placed on examining the capacity of Rooibos tea to influence production of inflammatory mediators, including NO, iNOS, COX-2, and cytokines in the murine macrophage Raw 264.7 cell model. Experiments were performed both with and without IFN- $\gamma$ and lipopolysaccharide (LPS) stimulation.

\section{MATERIALS AND METHODS \\ Materials}

In this study, we used the following dry tea leaves: organic white peony (white tea), organic Mao Jian (green tea), Ti Kuan Yin (oolong tea), organic Wuyuan Imperial Keemun (black tea), organic Cedarberg Rooibos (fermented), and organic Yerba Mate from Teaguy Teas Inc. (Squamish, BC, Canada), all of which were donated by Wize Monkey Inc. (Vancouver, BC, Canada). 
Trifluoroacetic acid (TFA), rutin (Ru), gallic acid (GA), green tea catechin mix including caffeine $(\mathrm{CAF})$, gallocatechin (GC), catechin (C), epicatechin (EC), epigallocatechin gallate (EGCG), gallocatechin gallate (GCG), catechin gallate (CG), and epicatechin gallate (ECG), in addition to Folin Ciocolteau reagent, 2,2-Diphenyl-1-picrylhydrazyl (DPPH), 2,2-Azino-bis(3ethylbenzthiazoline-6-sulphonic acid (ABTS), 2,2'-Azobis(2-amidinopropane) dihydrochloride (AAPH), fluorescein sodium salt $( \pm$ )-6-Hydroxy-2,5,7,8-tetramethylchromane-2-carboxylic acid (Trolox), 3-(4,5-Dimethylthiazol-2-yl)-2,5-diphenyltetrazolium bromide (MTT), IFN- $\gamma$, LPS, sodium nitrite, Dulbecco's Modified Eagle's Medium (DMEM), Bradford reagent, bovine serum albumin (BSA), and anti-iNOS for mouse primary antibody that were purchased from SigmaAldrich (St. Louis, MO, USA). 3-Caffeoylquninic acid (3-CQA), 5-caffeoylquninic acid (5-CQA), 3,4-dicaffeoylquninic acid (3,4-diCQA), 3,5-dicaffeoylquninic acid (3,5-diCQA), and 4,5dicaffeoylquninic acid (4,5-diCQA) standards were purchased from Chengdu Must BioTechnology Co., Ltd. (Chengdu, China). Acetonitrile (ACN) was purchased from Thermo Fisher Scientific (Waltham, MA, USA). Raw 264.7 (TIB-71) was purchased from ATCC (Manassas, VA, USA). Anti-beta actin ( $\beta$-actin) primary antibodies and anti-Immunoglobulin G (IgG) secondary antibody were purchased from Abcam (Cambridge, UK). Anti-COX-2 was purchased from Cayman Chemical Company (MI, USA). Single cytokine enzyme-linked immunosorbent assay (ELISA) kits including IL-1 $\alpha$, IL-1 $\beta$, IL-6, IL-10, G-CSF, GM-CSF, and TNF- $\alpha$ were purchased from Qiagen (Hilden, Germany). Nitrocellulose membrane and Western enhanced chemiluminescence (ECL) substrate were purchased from Bio-Rad (Hercules, CA, USA).

\section{Hot water infusion}

Using dried tea leaves from six teas from different sources, the dried tea leaves were ground to a powder using a coffee grinder. Tea leaf powder $(5 \mathrm{~g})$ was extracted with $100 \mathrm{~mL}$ of boiling water for $0.5,10$, and 20 min respectively. Samples were cooled and for filtration Whatman® No. 4 filter paper was used, after which the supernatant was freeze-dried and stored at $4{ }^{\circ} \mathrm{C}$ until further analysis. All of the extractions are prepared in triplicate.

\section{Determination of phytochemicals using HPLC}

The hot water extract was dissolved in $18 \Omega$ Milli-Q deionized water at a concentration of $2 \mathrm{mg} / \mathrm{mL}$. Phytochemicals in tea extracts were measured using an Agilent 1100 LC system (Agilent, Santa Clara, CA, USA) equipped with a Phenonenex Kinetex C18 $(100 \times 4.8,5 \mu \mathrm{m})$ column and a diode array detector (DAD). Chlorogenic isoforms, 3-CQA, 5-CQA, 3,4-diCQA, 3,5-diCQA, and 4,5diCQA, in addition to phenolics, gallic acid and rutin, were analyzed using the method described by Craig et al. [21]. The mobile phase included A: 0.1\% TFA in water and B: ACN. The HPLC gradient was set as followed: $5-20 \%$ of B, $0-10 \mathrm{~min} ; 20 \%$ of B, $10-12 \mathrm{~min} ; 20-5 \%$ of B, 12-15 min; $95 \%$ of $\mathrm{B}, 15.1-16.5 \mathrm{~min} ; 5 \%$ of $\mathrm{B}, 16.6-19 \mathrm{~min}$. Chlorogenic acid isoforms were detected at 330 $\mathrm{nm}$, rutin was detected at $257 \mathrm{~nm}$, and gallic acid was detected at $280 \mathrm{~nm}$. Caffeine and catechins were quantified using a gradient mobile phase including A; 0.1\% TFA in 5\% ACN and mobile phase $\mathrm{B}, 0.1 \%$ TFA in ACN. A gradient elution was performed as the following: $0 \%$ of $\mathrm{B}, 0-1.2$ $\min ; 0-71.5 \%$ of $\mathrm{B}, 1.2-15 \mathrm{~min} ; 71.5 \%$ of $\mathrm{B}, 15-17 \mathrm{~min} ; 0 \%$ of $\mathrm{B}, 17.01-19 \mathrm{~min}$. The DAD was set at $280 \mathrm{~nm}$. The flow rate was $1.5 \mathrm{~mL} / \mathrm{min}$ and the column temperature was set at $25^{\circ} \mathrm{C}$.

\section{Measurement of total phenolic content (TPC)}

TPC was measured using Folin-Ciocalteu assay, described by Chen et al.[22] with minor modifications. A hot water infusion extract was briefly dissolved in $\mathrm{ddH}_{2} \mathrm{O}$ at a concentration of 
$20 \mathrm{mg} / \mathrm{mL}$, followed by dilution in $\mathrm{ddH}_{2} \mathrm{O}$. Gallic acid standard and samples were reacted with $100 \mu \mathrm{L}$ of Folin Ciocolteau reagent (1: 10 dilution) in a 96-well plate and then incubated at room temperature for $1 \mathrm{~min}$. This was followed by reacting the mixture with $80 \mu \mathrm{L}$ of $75 \mathrm{mg} / \mathrm{mL} \mathrm{Na}_{2} \mathrm{CO}_{3}$ solution for $30 \mathrm{~min}$. Absorbance readings were read using a spectrophotometer (Multiskan Ascent, Thermo Labsystems, Helsinki, Finland) at $765 \mathrm{~nm}$. Total phenolic content was expressed as mg gallic acid/g leaf. All the measurements are performed in triplicate.

\section{Measurement of DPPH free radical scavenging activity}

The DPPH free radical scavenging capacity of hot water extract was performed as described by $\mathrm{Hu}$ et al. [23] with modifications. The hot water extract was briefly dissolved in $\mathrm{ddH}_{2} \mathrm{O}$ at a concentration of $20 \mathrm{mg} / \mathrm{mL}$, followed by appropriate dilution to working concentrations in methanol. Then then $180 \mu \mathrm{L}$ series diluted samples or Trolox standard were incubated with $20 \mu \mathrm{L}$ of $1 \mathrm{mmol} / \mathrm{L} \mathrm{DPPH}$ in $100 \%$ methanol at room temperature for $10 \mathrm{~min}$ in the dark. The sample absorbance at $519 \mathrm{~nm}$ was recorded by spectrophotometer (Multiskan Ascent, Thermo Labsystems, Helsinki, Finland). The inhibition of the DPPH free radical was calculated as the following:

$$
\% \text { Inhibition }=\left(\mathrm{Abs}_{\text {control }}-\mathrm{Abs}_{\text {sample }}\right) /\left(\mathrm{Abs}_{\mathrm{control}}-\mathrm{Abs}_{\mathrm{blank}}\right) \times 100
$$

Eq 1. where $\mathrm{Abs}_{\text {control }}=$ absorbance of $0.1 \mathrm{mM} \mathrm{DPPH}$ alone in methanol, $\mathrm{Abs}_{\text {sample }}=$ absorbance of $0.1 \mathrm{mM} \mathrm{DPPH}+$ sample in methanol, and $\mathrm{Abs}_{\text {blank }}=$ absorbance of methanol solvent control in absence of DPPH and sample.

\section{Measurement of ABTS free radical scavenging activity}

The affinity of hot water tea extracts to scavenge ABTS radicals was performed as described by Chen et al. [24]. $5 \mathrm{~mL}$ of $7 \mathrm{mmol} / \mathrm{L}$ ABTS was briefly mixed with $88 \mu \mathrm{L}$ of $140 \mathrm{mmol} / \mathrm{L} \mathrm{K}_{2} \mathrm{~S}_{2} \mathrm{O}_{8}$

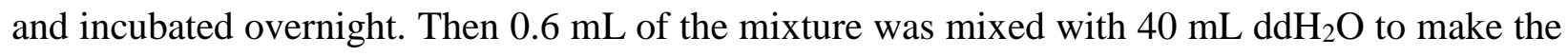
ABTS working solution. Properly diluted samples or Trolox $(0-20 \mu \mathrm{L})$ were incubated with 180 $\mu \mathrm{L}$ of the ABTS working solution for $10 \mathrm{~min}$ at room temperature in the dark; the absorbance was read at $734 \mathrm{~nm}$. The Trolox equivalent antioxidant capacity (TEAC) was calculated using slope of sample/slope of Trolox and expressed as $\mu \mathrm{mol}$ Trolox/g leaf.

\section{Measurement of oxygen radical absorbance capacity (ORAC)}

ORAC assay was based on the method described by Chen and Kitts [25]. The hot water extract, or Trolox standard, was briefly diluted in $75 \mathrm{mmol} / \mathrm{L}$ of phosphate buffer $(\mathrm{pH} 7.0$ ) and incubated with $60 \mu \mathrm{L}$ of $200 \mathrm{nmol} / \mathrm{L}$ fluorescein sodium salt and $40 \mu \mathrm{L}$ of $60 \mathrm{mmol} / \mathrm{L}$ AAPH at $37^{\circ} \mathrm{C}$ for $60 \mathrm{~min}$. Fluorescence $($ excitation $=485 \mathrm{~nm}$; emission $=527 \mathrm{~nm}$ ) was continuously read for up to $60 \mathrm{~min}$ in 96-well plate using a fluorescent microplate reader (Fluoroskan Ascent FL, Thermo Labsystems, Helsinki, Finland); the area under the curve was calculated to get the slope. ORAC = slope of sample/slope of Trolox (expressed as $\mu \mathrm{mol}$ Trolox/g leaf).

\section{Measurement of nitric oxide inhibitory activity}

The measurement of NO in Raw 264.7 cells was performed according the method described by Chen and Kitts [26] with modifications. Raw 264.7 cells were briefly seeded on a 96-well plate at a density of $10^{5}$ cells/well in complete DMEM and incubated overnight. The cells were pre-treated with samples in fresh DMEM without FBS for 30 min followed by treatment with $50 \mathrm{ng} / \mathrm{mL}$ of 
LPS and $10 \mathrm{ng} / \mathrm{mL}$ of IFN- $\gamma$ for another $18 \mathrm{~h}$ to induce NO. Cell culture supernatant $(100 \mu \mathrm{L})$ was reacted with $100 \mu \mathrm{L}$ Griess reagent to form a pink color which was measured at $540 \mathrm{~nm}$. Sodium nitrite was used as the standard. The percentage inhibition (\%) was calculated using equation 2. Cell viability was determined using MTT assay described by Chen and Kitts [26]. Only cells with a viability greater than $90 \%$ were used.

$$
\% \text { Inhibition }=\left(\mathrm{NO}_{\text {control }}-\mathrm{NO}_{\text {sample }}\right) /\left(\mathrm{NO}_{\text {control }}-\mathrm{NO}_{\text {blank }}\right) \times 100
$$

Eq 2. where $\mathrm{NO}_{\text {control }}=\mathrm{NO}$ content of cells induced with LPS $+\mathrm{IFN}-\gamma, \mathrm{NO}_{\text {sample }}=\mathrm{NO}$ content of cells incubated with hot water extract and LPS + IFN- $\gamma$, and NOblank $=$ NO content of cells in absence of LPS + IFN- $\gamma$ and sample.

\section{Western blotting}

The expression of iNOS and COX-2 proteins in Raw 264.7 cells treated with the Rooibos tea extract were detected using Western blotting procedures described by Chen and Kitts [26], with minor modifications. Raw 264.7 cells were seeded in 6-well plates at a density of $10^{6}$ cells/well and cultured overnight. The Raw 264.7 cells were pre-incubated with Rooibos tea extract in $2 \mathrm{~mL}$ fresh DMEM without FBS for 30 min and then incubated with or without LPS $(50 \mathrm{ng} / \mathrm{mL})$ and IFN- $\gamma(10 \mathrm{ng} / \mathrm{mL})$ for $18 \mathrm{~h}$. The supernatant was collected and centrifuge at $1000 \times \mathrm{g}$ for $10 \mathrm{~min}$ and stored at $-20^{\circ} \mathrm{C}$ for cytokine analysis. Total protein was extracted and measured using Bradford reagent. After being adjusted to the same concentration, protein samples were loaded onto an $8 \%$ sodium dodecyl sulfate-polyacrylamide (SDS-PAGE) gels using a Mini-PROTEAN Tetra Cell Apparatus (Bio-Rad Laboratories, Hercules, CA, USA ) and then transferred to nitrocellulose membranes. After blocking with $3 \%$ BSA for $1 \mathrm{~h}$, the membranes were initially blotted with an anti-mouse iNOS and COX-2 antibody overnight at $4{ }^{\circ} \mathrm{C}$, and then with a secondary antibody, horse radish peroxidase-conjugated goat anti-rabbit $\mathrm{IgG}$, for $1 \mathrm{~h}$. The membranes were reacted against ECL substrate for $5 \mathrm{~min}$ and analyzed using a ChemiDoc ${ }^{\mathrm{TM}}$ MP Imaging System (Bio-Rad Laboratories).

\section{Measurement of cytokines}

IL-1 $\alpha$, IL-1 $\beta$, IL-6, IL-10, G-CSF, GM-CSF, and TNF- $\alpha$ were measured in the supernatant from the 6-well plate according to the manufacturer's instructions and using the appropriate sample dilution. $50 \mu \mathrm{L}$ of assay buffer was briefly added into each well, followed by $50 \mu \mathrm{L}$ of appropriated diluted samples or standards and then incubated at room temperature for $2 \mathrm{~h}$. Contents were washed thoroughly three times using $350 \mu \mathrm{L}$ wash buffer, followed by incubation with $100 \mu \mathrm{L}$ detection buffer for $1 \mathrm{~h}$. After being washed three times, the wells were incubated with Avidin-HRP conjugate for $30 \mathrm{~min}$ in the dark. The wells were then washed four times and incubated with 100 $\mu \mathrm{L}$ development solution for $15 \mathrm{~min}$ followed by $100 \mu \mathrm{L}$ stop solution. The plate was read at 450 $\mathrm{nm}$ with a reference of $570 \mathrm{~nm}$.

\section{Statistical analysis}

Data was analyzed using one-way analysis of variance (ANOVA) or two-way ANOVA, which was conducted using MINITAB software (Version 14, Minitab Inc., State College, Pa., U.S.A.). IC50s were calculated using Origin (OriginLab Corporation). The percentage contribution of each factor was calculated as the ratio of the sum squared deviations for each factor to the total sum of 
squared deviations. Accordingly, this analysis was used to evaluate the relative importance of the treatment factors on the response outcomes. Significant differences among samples were compared using Tukey's test. Data are expressed as means \pm SD of triplicate experiments, with $\mathrm{P}$ $<0.05$ representing a statistically significant difference.

\section{RESULTS}

\section{Phytochemical contents of different tea extract}

HPLC profiles of these six tea samples are shown in Figure 1 and the content of individual phytochemicals are listed in Table 1. Caffeine, rutin, gallic acid, and catechins including GC, C, EC, EGCG, GCG, and ECG were detected in Camellia sinensis teas, while chlorgenic acids including 3-CQA, 5-CQA, 3,4-diCQA, 3,5-diCQA, and 4,5-diCQA were detected in Yerba mate tea. However, our results also revealed that these particular phytochemicals were not detectable in Rooibos tea. For example, a very small amount of rutin was detected in Rooibos tea (data not shown). Caffeine was the most predominant phytochemical in all four of the Camellia sinensis teas, with white tea and oolong tea containing the most and the least caffeine content $(\mathrm{P}<0.05)$ respectively. Yerba mate tea contained less caffeine compared with the Camellia sinensis teas. Rutin content was more abundant in Yerba mate tea compared to the Camellia sinensis teas. Oolong tea had the least gallic acid content when compared with the white, green, and black teas. Although infusion time in brewing tea had a small impact on the caffeine and rutin content in Camellia sinensis teas and Yerba mate tea respectively, we observed that infusions of at least 10 min significantly increased gallic acid content in teas, compared with a shorter (e.g. $0.5 \mathrm{~min}$ ) infusion $(\mathrm{P}<0.05)$. EGCG was the major catechin in white, green, and oolong teas, followed by ECG. However, GCG was the most pre-dominant catechin in black tea. The order of total catechins of different teas followed the order of white tea $>$ green tea $>$ oolong tea $>$ black tea. 3-CQA and 5-CQA were relatively more abundant than 3,4-, 3,5-, and 4,5-diCQA in Yerba mate tea. The infusion time it took to brew the teas did not significantly affect the total chlorogenic acids extracted in Yerba mate tea. TPC (Table 2) in these six teas followed a descending order: white tea $>$ Yerba mate tea $>$ green tea $>$ oolong tea $>$ black tea $>$ Rooibos tea. Infusion time also had a minor effect on TPC.

\section{Antioxidant activity of different tea extract}

Antioxidant activities of teas were assessed using ABTS, ORAC, and DPPH assays, with the results being displayed in Table 2. Using the ABTS assay gave results for relative antioxidant activity in the following order of White tea > Green Tea > Oolong tea > Yerba mate tea > Black tea $>$ Rooibos tea. A similar result was obtained using the DPPH assay. A small difference in the order of antioxidant activity using the ORAC assay was observed with White tea > Green tea > Yerba mate tea $>$ Oolong tea $>$ Black tea $>$ Rooibos tea. The effects of infusion time on the antioxidant activity were affected by the type of teas and the methods used for antioxidant analysis. Overall, for ABTS and ORAC assays a longer infusion time (10 min) led to increased antioxidant activity when compared to the results of 0.5 min infusion.

\section{Effects of tea extract on $\mathrm{NO}$ production}

The IC50s of NO production in Raw 264.7 cells are shown in Table 2. Yerba mate tea and Rooibos tea had the greatest and least NO inhibitory activity respectively. The NO inhibitory capacity of 
white tea and black tea was relatively higher than that of green and oolong tea. Infusion time did not affect the NO inhibitory activity of Rooibos and Yerba mate teas. However, white, green, oolong, and black teas tended to have greater NO inhibitory activity when they were infused for longer time (10 or $20 \mathrm{~min}$ ), especially when compared the results of $0.5 \mathrm{~min}$ infusion. Significantly, only Rooibos tea induced NO production (Figure 2), in contrast to the other five teas in which this specific bioactive effect was not observed. The Rooibos tea induced NO production at a concentration that went as low as $4 \mu \mathrm{g} / \mathrm{mL}$ and reached maximum induction at around $16 \mu \mathrm{g} / \mathrm{mL}$. A decreased NO induction was evident at higher concentrations. Infusion time had significantly less impact on the phytochemical contents and bioactive properties compared to the impact of the type of tea used.

\section{Correlation of TPC, antioxidant and anti-inflammatory activities}

Table 3 shows a significant $(\mathrm{P}<0.05)$, positive correlation between TPC and antioxidant activity, which was measured using ABTS and ORAC assays. TPC was negatively correlated with IC50 of DPPH scavenging and NO inhibitory activities respectively, thereby indicating that the phenolic compounds in both tea and herbal teas are major contributors to the measured antioxidant and antiinflammatory activities. Moreover, the fact that the IC50 of NO inhibitory activity was also positively correlated with IC50 of DPPH scavenging activity and negatively correlated with ABTS and ORAC value indicates that the antioxidant components present in teas also have some antiinflammatory activity.

\section{Effects of Rooibos tea on iNOS and COX-2 in Raw 264.7 cells}

The effects of Rooibos on iNOS and COX-2 expression are shown in Figure 3. Similar to the impact of Rooibos tea on NO production, we found that Rooibos extracts also induced basal iNOS production. The induction of iNOS at lower concentration $(0.25 \mathrm{mg} / \mathrm{ml})$ was actually greater than exposure to tea extracts at a higher concentration $(1.0 \mathrm{mg} / \mathrm{ml})$. However, by challenging Raw 264.7 cells with IFN- $\gamma+$ LPS for the purpose of inducing an inflammatory state, we observed a dosedependent capacity of this tea extract to inhibit iNOS expression. Similar effects were found for COX-2 expression, except that Rooibos tea can upregulate COX-2 to much higher levels compared to iNOS. Nevertheless, the inhibitory effects were also observed to be significantly less than that of iNOS.

\section{Effects of Rooibos tea on pro-/anti-inflammatory cytokines in Raw 264.7 cells}

The direct effect of Rooibos tea to induce NO production corresponded to specific effects on cytokine production (Figure 4). Rooibos tea induced seven cytokines examined in Raw 274.7 cells. However, the dose effect required for an induction was specific to the cytokine being tested. For example, IL-1 $\alpha$, IL-6, G-CSF, GM-CSF, and TNF- $\alpha$, were induced more at a lower concentration (e.g. $0.25 \mathrm{mg} / \mathrm{mL}$ ) compared with that of a higher concentration (e.g. $1.0 \mathrm{mg} / \mathrm{mL}$ ). In contrast, Rooibos tea induced more IL-1 $\beta$ and IL-10 at higher (e.g. $1.0 \mathrm{mg} / \mathrm{mL}$ ) concentrations than lower concentrations. When cells were challenged with IFN- $\gamma+$ LPS, a dose-depended effect of the Rooibos tea extract was noted to inhibit IL-6 and IL-10 production. Only high concentrations of Rooibos tea extracts inhibited IL-1 $\alpha$, G-CSF, and GM-CSF production, while a low concentration $(0.25 \mathrm{mg} / \mathrm{mL})$ further up-regulated cytokine production. Moreover, Rooibos tea extract further upregulated IL-1 $\beta$ and TNF- $\alpha$ production in Raw 264.7 cells co-incubated with IFN- $\gamma+$ LPS. 

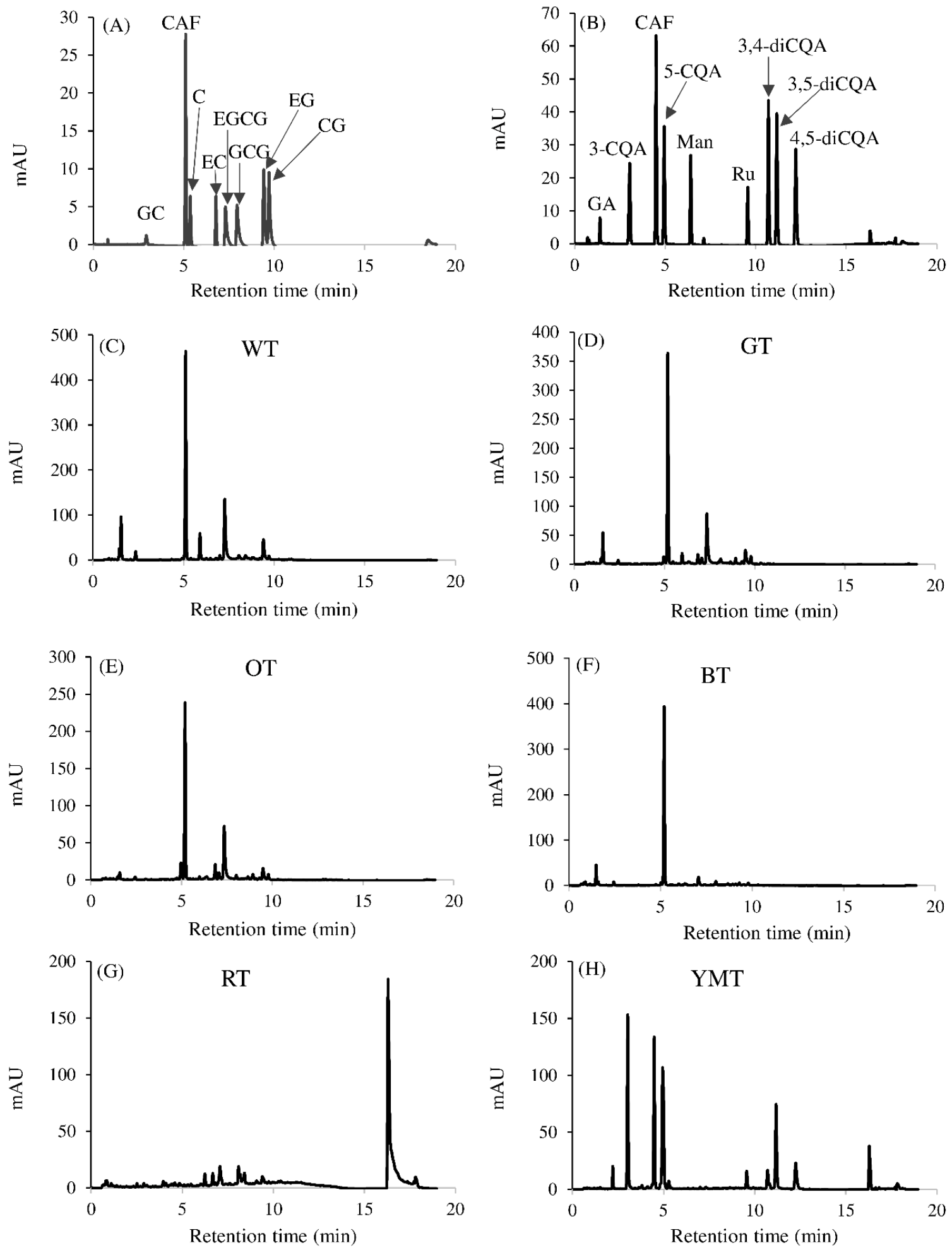

Figure 1. HPLC profiles of standards and four Camellia sinensis teas and two herbal teas. (A) Standard of catechins mixture, (B) Standards of Chologenic acids mixture, (C) White tea (WT), (D) Green tea (GT), (E) Oolong tea (OT), (F) Black tea (BT), (G) Rooibos tea (RT), (H) Yerba mate tea (YMT). Rutin (Ru), gallic acid (GA), mangiferin (Man), caffeine (CAF), gallocatechin (GC), catechin (C), epicatechin (EC), epigallocatechin gallate (EGCG), gallocatechin gallate (GCG), epicatechin gallate (ECG), 3-caffeoylquninic acid (3-CQA), 5-caffeoylquninic acid (5-CQA), 3,4-dicaffeoylquninic acid (3,4-diCQA), 3,5-dicaffeoylquninic acid (3,5-diCQA), and 4,5dicaffeoylquninic acid (4,5-diCQA). 
Table 1. Phytochemical contents of different tea beverages (mg/g leaf)

\begin{tabular}{|c|c|c|c|c|c|c|c|c|c|c|c|}
\hline Sample & $\begin{array}{l}\text { Time } \\
(\text { min) }\end{array}$ & CAF & Rutin & GA & GC & $\mathrm{C}$ & EC & EGCG & GCG & ECG & TC \\
\hline \multirow{3}{*}{$\begin{array}{l}\text { White } \\
\text { tea }\end{array}$} & 0.5 & $27.7 \pm 1.8 \mathrm{~b}$ & $0.9 \pm 0.3 \mathrm{gh}$ & $1.8 \pm 0.1 \mathrm{~d}$ & $0.2 \pm 0.0 \mathrm{ef}$ & $0.6 \pm 0.1 b$ & $0.7 \pm 0.0 \mathrm{e}$ & $13.3 \pm 2.3 \mathrm{a}$ & $0.1 \pm 0.0$ & $4.3 \pm 0.8 \mathrm{a}$ & $19.2 \pm 3.2 b$ \\
\hline & 10 & $30.6 \pm 1.7 \mathrm{a}$ & $0.7 \pm 0.0 \mathrm{gh}$ & $3.2 \pm 0.2 b$ & $0.2 \pm 0.0 \mathrm{ef}$ & $0.7 \pm 0.1 b$ & $0.9 \pm 0.1 \mathrm{e}$ & $14.0 \pm 2.3 \mathrm{a}$ & $0.4 \pm 0.1 \mathrm{de}$ & $4.7 \pm 0.9 \mathrm{a}$ & $21.0 \pm 3.3 \mathrm{ab}$ \\
\hline & 20 & $29.3 \pm 0.1 \mathrm{ab}$ & $3.2 \pm 0.1 b$ & $3.6 \pm 0.1 \mathrm{a}$ & $0.3 \pm 0.1 \mathrm{def}$ & $0.6 \pm 0.1 b$ & $0.9 \pm 0.1 \mathrm{e}$ & $15.0 \pm 0.7 \mathrm{a}$ & $1.0 \pm 0.3 \mathrm{abc}$ & $5.4 \pm 0.3 \mathrm{a}$ & $23.2 \pm 1.1 \mathrm{a}$ \\
\hline \multirow{3}{*}{$\begin{array}{l}\text { Green } \\
\text { tea }\end{array}$} & 0.5 & $19.3 \pm 0.6 \mathrm{~d}$ & $1.0 \pm 0.1 \mathrm{ef}$ & $0.8 \pm 0.0 \mathrm{f}$ & $0.3 \pm 0.0 \mathrm{de}$ & $0.7 \pm 0.1 b$ & $3.0 \pm 0.3 \mathrm{~d}$ & $8.3 \pm 0.7 b c$ & $1.0 \pm 0.1 \mathrm{abc}$ & $2.4 \pm 0.2 b c$ & $15.6 \pm 0.8 \mathrm{~d}$ \\
\hline & 10 & $22.1 \pm 0.8 \mathrm{c}$ & $1.2 \pm 0.0 \mathrm{~cd}$ & $1.2 \pm 0.0 \mathrm{e}$ & $0.9 \pm 0.1 \mathrm{c}$ & $0.9 \pm 0.1 \mathrm{a}$ & $3.4 \pm 0.2 \mathrm{~cd}$ & $9.3 \pm 0.9 b$ & $1.1 \pm 0.3 \mathrm{a}$ & $2.7 \pm 0.3 b$ & $18.3 \pm 1.0 \mathrm{bc}$ \\
\hline & 20 & $23.2 \pm 1.7 \mathrm{c}$ & $1.3 \pm 0.1 \mathrm{c}$ & $1.4 \pm 0.0 \mathrm{e}$ & $1.6 \pm 0.1 \mathrm{ab}$ & $1.0 \pm 0.1 \mathrm{a}$ & $3.1 \pm 0.2 \mathrm{~d}$ & $8.7 \pm 1.1 b$ & $1.0 \pm 0.3 \mathrm{ab}$ & $2.7 \pm 0.3 b c$ & $18.1 \pm 1.6 b c$ \\
\hline \multirow{3}{*}{$\begin{array}{l}\text { Oolong } \\
\text { tea }\end{array}$} & 0.5 & $13.6 \pm 0.5 \mathrm{e}$ & $0.6 \pm 0.0 \mathrm{~h}$ & $0.5 \pm 0.0 \mathrm{f}$ & $0.5 \pm 0.1 \mathrm{~d}$ & $0.1 \pm 0.0 \mathrm{~d}$ & $4.2 \pm 0.2 \mathrm{a}$ & $8.6 \pm 0.3 b$ & $0.5 \pm 0.0 \mathrm{~cd}$ & $1.8 \pm 0.1 \mathrm{bcd}$ & $15.7 \pm 0.8 \mathrm{~d}$ \\
\hline & 10 & $13.7 \pm 0.2 \mathrm{e}$ & $0.6 \pm 0.0 \mathrm{~h}$ & $0.7 \pm 0.0 \mathrm{f}$ & $1.3 \pm 0.2 b$ & $0.3 \pm 0.0 \mathrm{~cd}$ & $4.1 \pm 0.3 \mathrm{ab}$ & $7.3 \pm 0.1 b c$ & $0.7 \pm 0.0 \mathrm{bcd}$ & $1.6 \pm 0.0 \mathrm{~cd}$ & $15.3 \pm 0.6 \mathrm{~d}$ \\
\hline & 20 & $12.7 \pm 0.3 \mathrm{ef}$ & $0.6 \pm 0.0 \mathrm{~h}$ & $0.7 \pm 0.0 \mathrm{f}$ & $1.8 \pm 0.1 \mathrm{a}$ & $0.3 \pm 0.0 \mathrm{c}$ & $3.6 \pm 0.3 b c$ & $5.2 \pm 0.5 c$ & $0.7 \pm 0.0 \mathrm{bcd}$ & $1.1 \pm 0.2 \mathrm{de}$ & $12.7 \pm 1.2 \mathrm{e}$ \\
\hline \multirow{4}{*}{$\begin{array}{l}\text { Black } \\
\text { tea }\end{array}$} & 0.5 & $19.0 \pm 0.6 \mathrm{~d}$ & $0.9 \pm 0.0 \mathrm{fg}$ & $2.2 \pm 0.1 \mathrm{c}$ & $0.0 \pm 0.0 \mathrm{~g}$ & $0.0 \pm 0.0 \mathrm{e}$ & $0.0 \pm 0.0 \mathrm{f}$ & $0.2 \pm 0.0 \mathrm{~d}$ & $0.6 \pm 0.0 \mathrm{~cd}$ & $0.1 \pm 0.0 \mathrm{e}$ & $0.9 \pm 0.1 \mathrm{f}$ \\
\hline & 10 & $18.5 \pm 0.5 \mathrm{~d}$ & $1.0 \pm 0.0 \mathrm{def}$ & $3.2 \pm 0.1 \mathrm{~b}$ & $0.0 \pm 0.0 \mathrm{~g}$ & $0.0 \pm 0.0 \mathrm{e}$ & $0.0 \pm 0.0 \mathrm{f}$ & $0.2 \pm 0.1 \mathrm{~d}$ & $0.7 \pm 0.1 \mathrm{bcd}$ & $0.2 \pm 0.0 \mathrm{e}$ & $1.0 \pm 0.2 \mathrm{f}$ \\
\hline & 20 & $19.0 \pm 0.8 \mathrm{~d}$ & $1.0 \pm 0.1 \mathrm{cde}$ & $3.8 \pm 0.1 \mathrm{a}$ & $0.0 \pm 0.0 \mathrm{~g}$ & $0.0 \pm 0.0 \mathrm{e}$ & $0.0 \pm 0.0 \mathrm{f}$ & $0.2 \pm 0.1 \mathrm{~d}$ & $0.7 \pm 0.0 \mathrm{bcd}$ & $0.1 \pm 0.1 \mathrm{e}$ & $1.1 \pm 0.2 \mathrm{f}$ \\
\hline & $\begin{array}{l}\text { Time } \\
(\text { min) }\end{array}$ & CAF & Rutin & 3-CQA & 5-CQA & $\begin{array}{l}\text { 3,4- } \\
\text { diCQA }\end{array}$ & $\begin{array}{l}\text { 3,5- } \\
\text { diCQA }\end{array}$ & $\begin{array}{l}\text { 4,5- } \\
\text { diCQA }\end{array}$ & TCA & & \\
\hline \multirow{3}{*}{$\begin{array}{l}\text { Yerba } \\
\text { Mate } \\
\text { tea }\end{array}$} & 0.5 & $10.0 \pm 0.1 \mathrm{~g}$ & $3.9 \pm 0.1 \mathrm{a}$ & $19.3 \pm 0.3 \mathrm{a}$ & $18.0 \pm 0.5 b$ & $1.7 \pm 0.1 \mathrm{c}$ & $8.3 \pm 0.2 \mathrm{a}$ & $4.1 \pm 0.1 \mathrm{c}$ & $51.3 \pm 1.1 \mathrm{a}$ & & \\
\hline & 10 & $9.8 \pm 0.4 \mathrm{~g}$ & $3.8 \pm 0.3 \mathrm{a}$ & $17.7 \pm 0.7 b$ & $18.4 \pm 0.7 \mathrm{ab}$ & $2.1 \pm 0.2 b$ & $7.0 \pm 0.5 b$ & $4.8 \pm 0.5 b$ & $50.1 \pm 2.4 \mathrm{a}$ & & \\
\hline & 20 & $10.1 \pm 0.3 \mathrm{fg}$ & $3.9 \pm 0.1 \mathrm{a}$ & $17.0 \pm 0.3 b$ & $19.7 \pm 0.5 \mathrm{a}$ & $2.9 \pm 0.2 \mathrm{a}$ & $6.1 \pm 0.2 c$ & $5.9 \pm 0.2 \mathrm{a}$ & $51.6 \pm 1.3 \mathrm{a}$ & & \\
\hline
\end{tabular}

CAF, caffeine; GA, gallic acid; GC, gallocatechin; C, catechin; EC, epicatechin; EGCG, epigallocatechin gallate; GCG, gallocatechin ECG, epicatechin gallate; TC, total catechins (the sum of GC, C, EC, EGCG, GCG and ECG); 3-CQA, 3-caffeoylquninic acid; 5-CQA, 5caffeoylquninic acid; 3,4-diCQA, 3,4-dicaffeoylquninic acid; 3,5-diCQA; 3,5-dicaffeoylquninic acid; 4,5-diCQA, 4,5-dicaffeoylquninic acid; TCA, total chologenic acids (the sum of 3-CQA, 5-CQA,3,4-diCQA, 3,5-CQA, and 4,5-diCQA). These compounds were either not detectable or present in very low concentrations in Rooibos tea.

Data in the same column that do not share the same letters signify significant difference $(\mathrm{P}<0.05)$. 
Table 2. Extraction yield, TPC, antioxidant, and NO inhibitory activity of teas

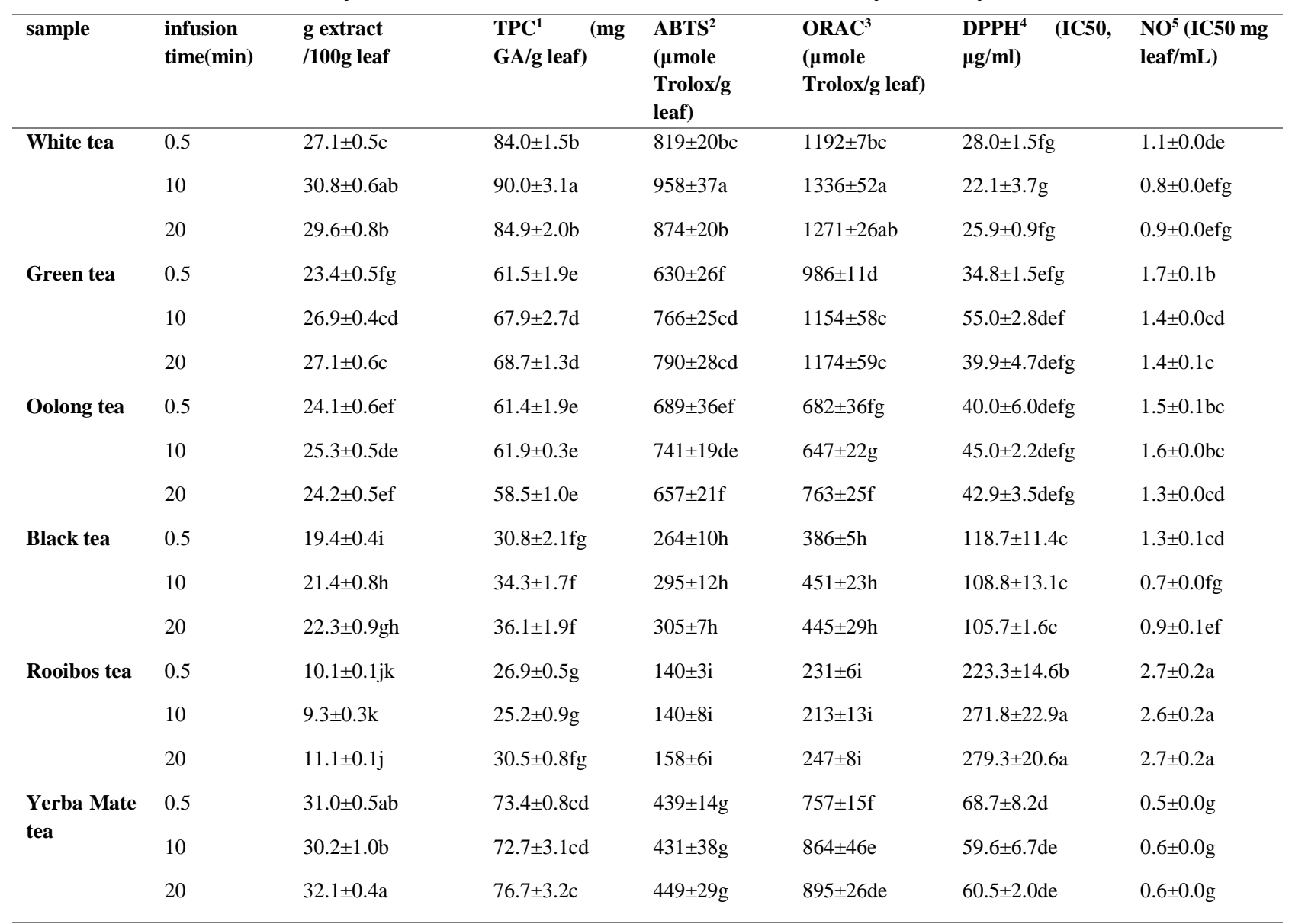

${ }^{1}$ Total Phenolic content (TPC), expressed as mg gallic acid/g leaf; ${ }^{2}$ Trolox equivalent antioxidant capacity measured by ABTS method; ${ }^{3}$ Trolox equivalent antioxidant capacity measured by ORAC assay; ${ }^{3}$ Half inhibitory capacity (IC50, $\mu \mathrm{g}$ leaf $/ \mathrm{mL}$ ) measured by DPPH assay; ${ }^{4}$ Half inhibitory capacity (IC50, $\mu \mathrm{g}$ leaf $/ \mathrm{mL}$ ) of nitric oxide inhibitory activity.

Data in the same column that do not share the same letters signify significant difference $(\mathrm{P}<0.05)$.

Table 3. Correlation coefficient among TPC, antioxidant, and anti-inflammatory activities

\begin{tabular}{lllll}
\hline & TPC $^{\mathbf{1}}$ & ABTS $^{\mathbf{2}}$ & ORAC $^{3}$ & DPPH $^{4}$ \\
\hline ABTS & $0.856^{*}$ & & & \\
ORAC & $0.928^{*}$ & $0.907^{*}$ & & \\
DPPH & $-0.816^{*}$ & $-0.837^{*}$ & $-0.817^{*}$ & \\
NO & $-0.621^{*}$ & $-0.418^{*}$ & $-0.548^{*}$ & $0.741^{*}$
\end{tabular}

${ }^{1}$ Total Phenolic content (TPC), expressed as mg gallic acid/g leaf; ${ }^{2}$ Trolox equivalent antioxidant capacity measured by ABTS method; ${ }^{3}$ Trolox equivalent antioxidant capacity measured by ORAC assay; ${ }^{3}$ Half inhibitory capacity (IC50, $\mu \mathrm{g}$ leaf $/ \mathrm{mL}$ ) measured by DPPH assay; ${ }^{4}$ Half inhibitory capacity (IC50, $\mu \mathrm{g}$ leaf/mL) of nitric oxide inhibitory activity.

\footnotetext{
* Asterisk denotes significant correlation with $\mathrm{P}<0.01$.
} 

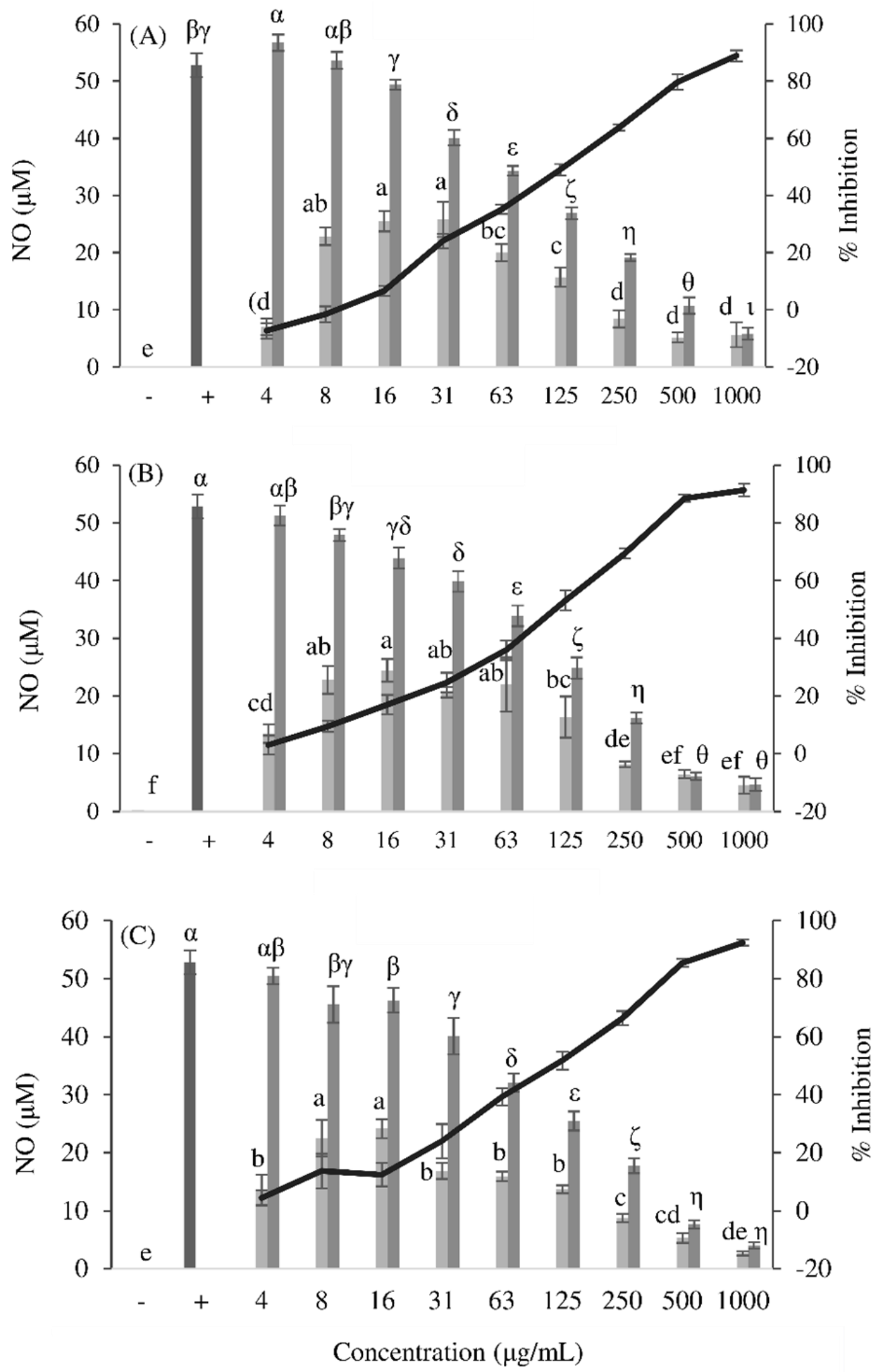

without IFN- $\gamma+$ LPS with IFN- $\gamma+$ LPS $-\%$ Inhibition

Figure 2. Effects of Rooibis tea on nitric oxide (NO) production in Raw 264.7 cells with or without IFN- $\gamma$ + LPS. (A) $0.5 \mathrm{~min}$, (B) $10 \mathrm{~min}$, and (C) $20 \mathrm{~min}$-, Blank, cells without sample and inducers (IFN- $\gamma+$ LPS); +, positive control, cells induced by IFN- $\gamma+$ LPS in the absent of sample. 

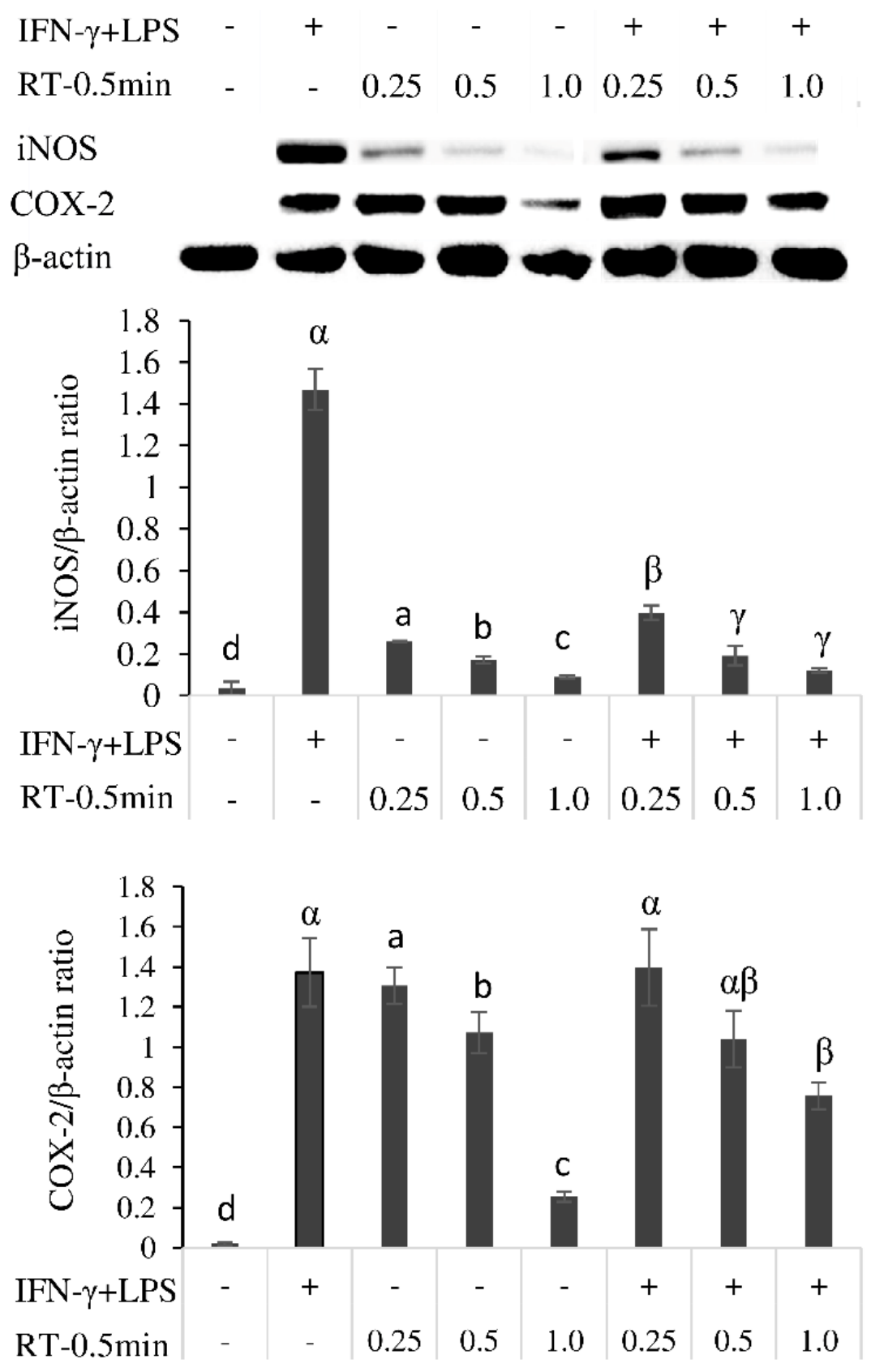

Figure 3. Effects of Rooibos tea (0.5 min extract) on iNOS and COX-2 expression in Raw 264.7 cells with or without IFN- $\gamma+$ LPS.

a-d Alphabet letters compare Rooibos tea without induction to blank (cells without sample and inducer (IFN- $\gamma+$ LPS $)$ ). Bars that do not share the same letter signify significant difference $(\mathrm{P}<$ $0.05)$.

${ }^{\alpha-\gamma}$ Greek alphabet letters compare Rooibos tea with induction to positive control (cells without sample, but with inducer (IFN- $\gamma+$ LPS)). Bars that do not share the same letter signify significant difference $(\mathrm{P}<0.05)$.

The concentrations used in this assay are $\mathrm{mg}$ extract/mL. 

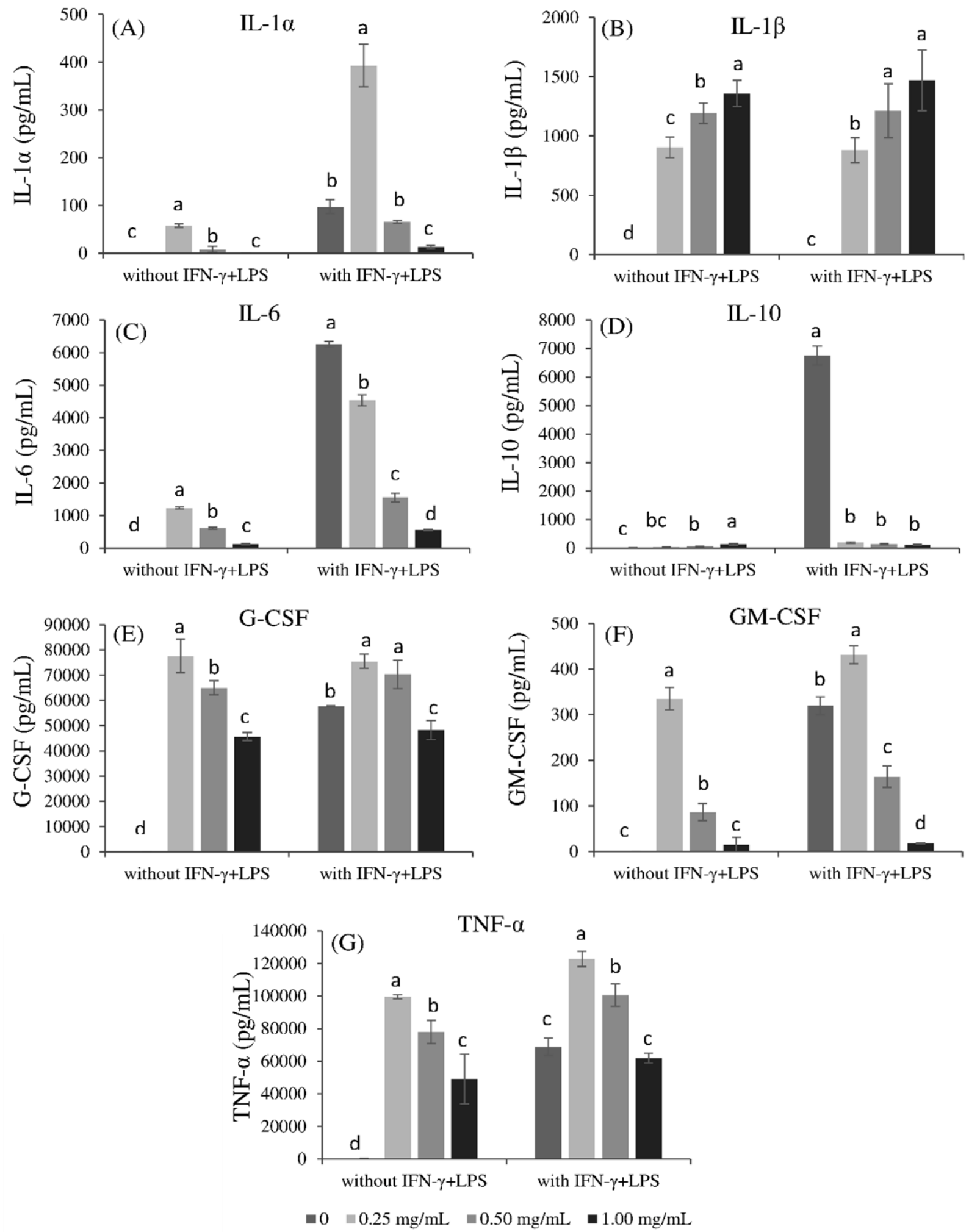

Figure 4. Effects of Rooibos tea on cytokines' production in Raw 264.7 cells with or without induction by IFN- $\gamma+$ LPS. (A) IL-1 $\alpha$, (B) IL-1 $\beta$, (C) IL-6, (D) IL-10, (E) G-CSF, (F) GM-CSF, and (G) TNF- $\alpha$.

a-d Alphabet letters compare Rooibos tea treatment in the same group. Bars that do not share the same letter signify significant different $(\mathrm{P}<0.05)$.

The concentrations used in this assay are $\mathrm{mg}$ extract $/ \mathrm{mL}$. 


\section{DISCUSSION}

There are numerus studies that have characterized the various bioactivities attributed to teas. However, there is still a paucity of data on how specific indices of bioactivity that impact oxidative stress or inflammatory mechanisms are influenced by the phytochemical composition of tea. A previous study done by Carloni et al.[1] showed that TPC derived from green tea was greater than from white tea and black tea. Our study demonstrated that TPC was actually present in greater concentrations in white tea, which corresponded to greater antioxidant activity compared to green tea. With the processing of tea, we observed a decline in TPC and corresponding lower indices of antioxidant and anti-inflammatory activities. Altogether, these results indicate that the phytochemical profiles and corresponding antioxidant activity of teas is dependant on a wide variety of factors that needs to be considered, including the tea's variety, its growing and manufacture conditions, age of the leaves, and additional post-harvest variables such as particle size, packaging type, and infusion conditions (e.g. tea to water ratio, infusion time, agitation) [1, 27]. Black tea contains much lower catechins due to the fermentation process which oxidizes catechins into theaflavin and thearubigin. A study conducted by Von Gadow et al. [28] found that the descending order of DPPH scavenging capacity of different teas was the following: green > unfermented rooibos $>$ fermented rooibos $>$ semifermented rooibos $>$ black $>$ oolong. In our study, we discovered that white tea had the greatest TPC and antioxidant activity. Rooibos teas actually had the lowest DPPH radical scavenging activity among the six teas we tested. We attribute our finding to the relatively lower amount of total water-soluble solids present in Rooibos tea compared to other teas; this was an observation also reported by Von Gadow et al. [28]. Additionally, Bastos et al. [29] found that Yerba mate tea contained greater phenolic content compared to that of green tea, which also corresponded to greater DPPH scavenging capacity.

Catechins are generally regarded as those phytochemicals that contribute the most to the antioxidant activity of Camellia sinensis tea. The antioxidant activity of catechins has been attributed to radical scavenging and metal ion-chelating capacity, which is dependent on catechin structure. Hydroxyl groups located on C-3', C-4', and C-5' of B ring and /or C-3 on A ring have relatively higher antioxidant activity, due to its ability to participate in electron dislocation and stabilize peroxyl radicals through hydrogen bonding [30,31]. Therefore, EGCG and EGC, based on their structure and that they are also the predominant catechins in Camellia sinensis, contributes the most to antioxidant capacity compared to the other catechins [2]. Green Rooibos tea has much higher antioxidant activity than fermented red Rooibos tea due to the oxidation of aspalathin, a relatively high antioxidant capacity compound that exists in Rooibos tea, to products such as orientin and iso-orientin, which possess relatively less antioxidant capacity [15].

Reactive oxygen species are not only involved in oxidative stress but can also trigger inflammatory responses. Our study confirmed that the anti-inflammatory activities of teas tested correlated with antioxidant activity, which in turn also related to the levels of TPC. Green tea was found to have greater NO inhibitory activity compared to that of herbal teas, which included rosemary, jasmine, and lemongrass [32]. Black tea only possessed half the NO inhibitory activity compared to green tea because of the reduced polyphenolic compounds resulting from fermentation [33]. Green tea, black tea, and Rooibos tea have been shown to increase NO production in human umbilical vein cells [34]. However, an in vivo study discovered that these teas had no effect on NO concentration in healthy human subjects. Both green and Rooibos teas 
have been reported to exhibit anti-hypertension effects through the inhibition of angiotensionconverting enzyme (ACE) [35]. Among all the catechins, EGCG was found to be the most active inhibitor of NO activity [36]. The NO inhibitory capacity of Yerba mate tea has been related to the presence of chlorogenic acids, especially diCQAs which inhibits the nucleus translocation of NF$\mathrm{kB}$ subunits p65 and p50 and the binding of NF-kB to its target DNA. The result is inhibition of transcription of genes with pro-inflammatory properties, such as COX-2, iNOS, and PGE2 [37]. The in vitro results of our study revealed that Rooibos tea was an inducer of NO production in unstimulated Raw 264.7 cells. However, white, green, oolong, black, and Yerba mate teas also demonstrated a similar capacity to stimulate NO production. Expanding on this observation, we further examined the anti-inflammatory activity of Rooibos tea by testing potential effects of this tea on iNOS, COX-2, and a battery of cytokines involved in inflammatory responses.

Inflammation has important dual functions on the maintenance of human health. On the one hand, it is a protective response against micro-organism, toxin or allergen-induced injury; on the other hand, inflammation can contribute to chronic and uncontrolled inflammation and related deleterious tissue effects [20]. Various diseases, including rheumatoid arthritis, atherosclerosis, asthma, and inflammatory bowel diseases are closely related to inflammation sensitive conditions. Pro-inflammatory cytokines such as, IL-1, TNF, IL-6, and GM-CSF are released during the inflammatory response [20]. IL-1 and TNF are primary inflammatory cytokines that mediate acute inflammation, while IL-1 is produced by mononuclear phagocytes, fibroblasts, keratinocytes, and $\mathrm{T}$ and B lymphocytes [17]. IL-1 $\alpha$ and IL-1 $\beta$ induce prostaglandin E2 (PGE2) synthesis and T cell proliferation, thereby triggering fever. They also trigger mast cell release of histamine at the site of inflammation to increase vascular permeability. TNF- $\alpha$ is produced in the activated macrophages/monocytes, fibroblasts, mast cells, T, and natural killer cells. Similar to IL-1, TNF$\alpha$ also triggers fever by inducing PGE2 or indirectly inducing IL-1 [17]. The expression of IL-1 and TNF- $\alpha$ will stimulate IL-6 synthesis, thereby further triggering secondary inflammatory reactions [17]. IL-6, a dual function (pro-inflammatory and anti-inflammatory) cytokine that is secreted from immune cells including monocytes, macrophages, lymphocytes, and mast cells, has an important role in innate immunity [38]. IL-6 stimulates acute phase protein synthesis and activates the differentiation of $\mathrm{B}$ cells and $\mathrm{T}$ cells to stimulate inflammation and induce synthesis in the IL-2 and IL-2 receptors [17, 38]. G-CSF and GM-CSF are colony stimulating factors produced in monocytes, T-cells, fibroblasts, and endothelial cells after activation by cytokines such as IL-1 or TNF [17]. IL-10 is an anti-inflammatory cytokine produced by cells involved in the innate and the adaptive immune system, including macrophages, T-cells, and B cells [39]. It reduces antigen-specific $\mathrm{T}$ cell proliferation, IL-2, induced IFN- $\gamma$ production in NK cells, and IL4 and IFN- $\gamma$ induced MHC class II expression on monocytes [40]. IL-10 plays an important role in preventing excessive tissue damage caused by bacterial and viral infections and proinflammatory responses [39].

Previous workers have shown that Rooibos tea inhibits IL-6 and IL-10 secretion while upregulating TNF- $\alpha$ and having significant inhibitory effects on iNOS expression [20]. Another study conducted by Smith and Swart [41] found that Rooibos tea also decreased IL-6, but increased IL10 in rats. Rooibos tea has also been shown to increase IL-2 and inhibit IL-4 production in ovalbumin-induced splenocytes, thereby indicating the potential efficacy in mitigating diseases such as cancer, allergy, acquired immune deficiency syndromes (AIDS), and other kinds of 
infection [42]. Rooibos tea has also been shown to have cardio-protective properties through improving the aortic output recovery in the hearts of rats, which was related to its unique flavonol content [43], while also preventing dextran sodium sulfate-induced DNA damage and inflammation in rats through its antioxidant activity [13].

In the present study, we report that Rooibos tea induced IL-1 $\alpha$, IL-1 $\beta$, IL-6, G-CSF, GMCSF, TNF- $\alpha$, iNOS, and and COX-2 in unstimulated Raw 264.7 cells. The immunostimulatory effect of Rooibos tea on a number of pro-inflammatory cytokines may activate the immune system to produce acute phase proteins, which in turn are needed to activate complements and to allow for the phagocytosis of pathogens; the final result is an anti-microbial response [44]. The efficacy of Rooibos tea in increasing NO production is an additional factor in potentially mitigating cardiovascular diseases and hypertension. Dose-dependent increase of IL-10 in unstimulated Raw 264.7 cells indicated that Rooibos tea components are involved in the activation and differentiation of B cells, which thereby prevents infection [44]. Under inflammatory conditions, Rooibos tea demonstrated anti-inflammatory activity by a similar dose-dependently inhibition of IL-6, iNOS, and COX-2. Treating cells with higher concentrations of Rooibos tea extracts lead to inhibitory effects on IL-1 $\alpha$, G-CSF, and GM-CSF, while lower concentrations were related to proinflammatory effects. These results point to the fact that the concentration of TPC in Rooibos tea is relatively specific to trigger an anti-inflammatory reaction. The inhibition effects of Rooibos tea extracts on IL-10 in presence of IFN- $\gamma+$ LPS suggested that Rooibos tea may affect those cytokines required for an effective immune response [44]. Accordingly, Lee and Bar [45] found that two major bioactive compounds aspalathin and nothofagin in Rooibos tea were involved in inhibiting TNF- $\alpha$, IL-6, and iNOS expression. Moreover, the activation of NF- $\kappa$ B in LPS-induced human umbilical vein endothelial cells support the fact that bioactive compounds in Rooibos tea have value in reducing vascular inflammation.

\section{CONCLUSION}

In conclusion, the infusion time for tea preparation was shown to have much less impact on the antioxidant and anti-inflammatory activities of different teas than the source of the tea extracts themselves. Among all these six teas tested, we found that the Rooibos tea possessed the lowest antioxidant and anti-inflammatory activities. The anti-inflammatory activity of teas was shown to be related to antioxidant activity and phytochemical composition. Specifically, Rooibos tea could produce a dual effect on inflammation, being capable of inhibiting inflammation under a pathogenic condition in addition to preventing microbial invasion through the production of proinflammatory cytokines. Furthermore, the capacity to induce NO makes Rooibos tea a plausible candidate to reduce blood pressure and prevent cardiovascular diseases.

List of Abbreviations: AIDS, acquired immune deficiency syndromes; ACN, Acetonitrile; AAPH, 2,2'-Azobis(2-amidinopropane) dihydrochloride; ABTS, 2,2-Azino-bis(3-ethylbenzthiazoline-6sulphonic acid; 3-CQA, 3-caffeoylquninic acid; 5-CQA, 5-caffeoylquninic acid; C, catechin; CG, catechin gallate; COX-2, cyclooxygenase 2; 3,4-diCQA, 3,4-dicaffeoylquninic acid; 3,5-diCQA, 3,5-dicaffeoylquninic acid; 4,5-diCQA, 4,5-dicaffeoylquninic acid; MTT, 3-(4,5-Dimethylthiazol2-yl)-2,5-diphenyltetrazolium bromide; DPPH, 2,2-Diphenyl-1-picrylhydrazyl; DMEM, Dulbecco's Modified Eagle's Medium; ELISA, enzyme-linked immunosorbent assay; ECL, 
enhanced chemiluminescence; EC, epicatechin; ECG, epicatechin-3-gallate; EGCG, epigallocatechin-3-gallate; EGC, epigallocatechin; GA, gallic acid; GC, gallocatechin; GCG, gallocatechin gallate; G-CSF, granulocyte-colony stimulating factor; GM-CSF, granulocyte macrophage colony-stimulating factor; Trolox, $( \pm$ )-6-Hydroxy-2,5,7,8-tetramethylchromane-2carboxylic acid; iNOS, inducible nitric oxide synthase; IFN- $\gamma$, interferon $\gamma$; IL, interleukin; LPS, lipopolysaccharide; NO, nitric oxide; ORAC, oxygen radical absorbance capacity; Ru, rutin; TPC, total phenolic content; TFA, trifluoroacetic acid; TEAC, Trolox equivalent antioxidant capacity; TNF- $\alpha$ tumor necrosis factor- alpha.

Competing Interests: The authors declare that there is no conflict of interest regarding the publication of this article.

Authors' Contributions: Dr. Xiu-Min Chen designed the experiment, conducted the experiment, analyzed the data, and wrote the manuscript. Dr. Zhili Ma performed part of extraction and assisted with the TPC, ABTS, DPPH, and ORAC assays. Dr. David Kitts assisted with the experimental design and co-authored the manuscript.

Acknowledgments and Funding: This work was supported by NSERC-Engage and MITACS accelerate grants (DDK). We thank Arnaud Petitvallet from Wize Monkey Inc. (Vancouver, BC, Canada) for the kind donation of teas and contribution to MITACS accelerate grant.

\section{REFERENCES}

1. Carloni P, Tiano L, Padella L, Bacchetti T, Customu C, Kay A, Damiani E: Antioxidant activity of white, green and black tea obtained from the same tea cultivar. Food Res Int 2013; 53:900-908.

2. Karori S, Wachira F, Wanyoko J, Ngure R: Antioxidant capacity of different types of tea products. African Journal of Biotechnology 2007, 6: 2287-2296.

3. Butt M, Imran A, Sharif M, Ahmad RS, Xiao H, Imran M, Rsool H: Black tea polyphenols: a mechanistic treatise. Crit Rev Food Sci Nutr 2014, 54:1002-1011.

4. Seeram NP, Henning SM, Niu Y, Lee R, Scheuller HS, Heber D: Catechin and caffeine content of green tea dietary supplements and correlation with antioxidant capacity. J Agric Food Chem 2006, 54:1599-1603.

5. Yang J, Liu RH: The phenolic profiles and antioxidant activity in different types of tea. Int J Food Sci Tech. 2013; 48:163-171.

6. Dufresne CJ, Farnworth ER: A review of latest research findings on the health promotion properties of tea. J Nutr Biochem 2001, 12:404-421.

7. Schinella G, Neyret E, Cónsole G, Tournier H, Prieto JM, Ríos J, Giner RM: An aqueous extract of Ilex paraguariensis reduces carrageenan-induced edema and inhibits the expression of cyclooxygenase- 2 and inducible nitric oxide synthase in animal models of inflammation. Planta Med 2014, 80:961-968.

8. Bracesco N, Sanchez A, Contreras V, Menini T, Gugliucci A: Recent advances on Ilex paraguariensis research: minireview. J Ethnopharmacol 2011, 136:378-384. 
9. Heck CI, De Mejia EG. Yerba Mate Tea (Ilex paraguariensis): a comprehensive review on chemistry, health implications, and technological considerations. J Food Sci 2007, 72: R138-R151.

10. Bastos DHM, Oliveira Dd, Matsumoto RT, Carvalho PdO, Ribeiro ML: Yerba mate: pharmacological properties, research and biotechnology. Med Aromat Plant Sci Biotechnol 2007, 1:37-46.

11. McKay DL, Blumberg JB: A review of the bioactivity of South African herbal teas: rooibos (Aspalathus linearis) and honeybush (Cyclopia intermedia). Phytotherapy Research 2007, 21:1-16.

12. Joubert E, Ferreira D: Antioxidants of Rooibos tea-a possible explanation for its health promoting properties? SA JOURNAL OF FOOD SCIENCE AND NUTRITION 1996, 8:79-84.

13. Baba H, Ohtsuka Y, Haruna H, Lee T, Nagata S, Maeda M, Yamashiro Y, Shimizu T: Studies of anti-inflammatory effects of Rooibos tea in rats. Pediatrics International 2009, 51:700-704.

14. Ajuwon OR, Marnewick JL, Davids LM: Rooibos (Aspalathus linearis) and its Major Flavonoids-Potential Against Oxidative Stress-Induced Conditions. In Basic Principles and Clinical Significance of Oxidative Stress. Edited by Sivakumar Joghi Thatha Gowder; 2015.

15. Joubert E, Schultz H: Production and quality aspects of rooibos tea and related products. A review. Journal of Applied Botany and Food Quality 2012, 80:138-144.

16. Von Gadow A, Joubert E, Hansmann C: Comparison of the antioxidant activity of rooibos tea (Aspalathus linearis) with green, oolong and black tea. Food Chem 1997, 60:73-77.

17. Feghali CA, Wright TM: Cytokines in acute and chronic inflammation. Front Biosci. 1997, 2:d12-d26.

18. Alican I, Kubes P: A critical role for nitric oxide in intestinal barrier function and dysfunction. American Journal of Physiology-Gastrointestinal and Liver Physiology 1996, 33:G225.

19. Rees DD, Palmer RM, Moncada S: Role of endothelium-derived nitric oxide in the regulation of blood pressure. Proc Natl Acad Sci U S A 1989, 86:3375-3378.

20. Mueller M, Hobiger S, Jungbauer A: Anti-inflammatory activity of extracts from fruits, herbs and spices. Food Chem 2010, 122:987-996.

21. Craig AP, Fields C, Liang N, Kitts D, Erickson A: Performance review of a fast HPLCUV method for the quantification of chlorogenic acids in green coffee bean extracts. Talanta 2016, 154:481-485.

22. Chen X, Tait AR, Kitts DD: Flavonoid composition of orange peel and its association with antioxidant and anti-inflammatory activities. Food Chem 2017; 218:15-21.

23. Hu C, Yuan YV, Kitts DD: Antioxidant activities of the flaxseed lignan secoisolariciresinol diglucoside, its aglycone secoisolariciresinol and the mammalian lignans enterodiol and enterolactone in vitro. Food and Chemical Toxicology 2007, 45:2219-2227.

24. Chen X, Hu C, Raghubeer E, Kitts DD: Effect of high pressure pasteurization on bacterial load and bioactivity of Echinacea purpurea. J Food Sci 2010, 75:C613-C618. 
25. Chen X, Kitts DD: Correlating Changes That Occur in Chemical Properties with the Generation of Antioxidant Capacity in Different Sugar-Amino Acid Maillard Reaction Models. J Food Sci 2011, 76:C831-C837.

26. Chen X, Kitts DD: Evidence for inhibition of nitric oxide and inducible nitric oxide synthase in Caco-2 and RAW 264.7 cells by a Maillard reaction product [5-(5, 6-dihydro4H-pyridin-3-ylidenemethyl) furan-2-yl]-methanol. Mol Cell Biochem 2015.

27. Astill C, Birch MR, Dacombe C, Humphrey PG, Martin PT: Factors affecting the caffeine and polyphenol contents of black and green tea infusions. J Agric Food Chem 2001, 49:5340-5347.

28. von Gadow A, Joubert E, Hansmann CF: Comparison of the antioxidant activity of aspalathin with that of other plant phenols of rooibos tea (Aspalathus linearis), $\alpha$ tocopherol, BHT, and BHA. J Agric Food Chem 1997, 45:632-638.

29. Bastos DH, Saldanha LA, Catharino RR, Sawaya A, Cunha IB, Carvalho PO, Eberlin MN: Phenolic antioxidants identified by ESI-MS from yerba maté (Ilex paraguariensis) and green tea (Camelia sinensis) extracts. Molecules 2007, 12:423-432.

30. Bors W, Heller W, Michel C, Saran M: Radical chemistry of flavonoid antioxidants. In: Anonymous Antioxidants in Therapy and Preventive Medicine. Springer; 1990: 165-170.

31. Bors W, Heller W, Michel C, Saran M: Flavonoids as antioxidants: determination of radical-scavenging efficiencies. Methods Enzymol 1990, 186:343-355.

32. Tsai P, Tsai T, Yu C, Ho S: Comparison of NO-scavenging and NO-suppressing activities of different herbal teas with those of green tea. Food Chem 2007, 103:181-187.

33. Lin C, Lu M, Chen S, Ho S: Heavy fermentation impacts NO-suppressing activity of tea in LPS-activated RAW 264.7 macrophages. Food Chem 2006, 98:483-489.

34. Persson IA, Josefsson M, Persson K, Andersson RG: Tea flavanols inhibit angiotensinconverting enzyme activity and increase nitric oxide production in human endothelial cells. J Pharm Pharmacol 2006, 58:1139-1144.

35. Persson IA, Persson K, Hägg S, Andersson RG: Effects of green tea, black tea and Rooibos tea on angiotensin-converting enzyme and nitric oxide in healthy volunteers. Public Health Nutr 2010, 13:730-737.

36. Paquay JB, Haenen GR, Stender G, Wiseman SA, Tijburg LB, Bast A: Protection against nitric oxide toxicity by tea. J Agric Food Chem 2000, 48:5768-5772.

37. Puangpraphant S, Berhow MA, Vermillion K, Potts G, Gonzalez de Mejia E:

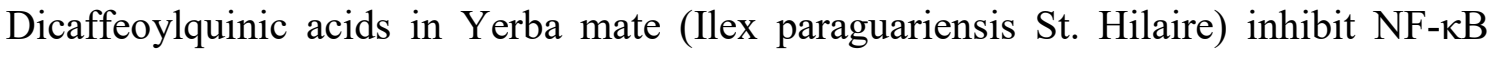
nucleus translocation in macrophages and induce apoptosis by activating caspases- 8 and3 in human colon cancer cells. Molecular nutrition \& food research 2011, 55:1509-1522.

38. Papanicolaou DA, Wilder RL, Manolagas SC, Chrousos GP: The pathophysiologic roles of interleukin-6 in human disease. Ann Intern Med 1998, 128:127-137.

39. Ouyang W, Rutz S, Crellin NK, Valdez PA, Hymowitz SG: Regulation and functions of the IL-10 family of cytokines in inflammation and disease. Annu Rev Immunol 2011, 29:71-109.

40. de Waal Malefyt R, Hans Y, Roncarolo M, Spits H, de Vries JE: Interleukin-10. Current Opinion in Immunology 1992, 4:314-320. 
41. Smith C, Swart AC: Rooibos (Aspalathus linearis) facilitates an anti-inflammatory state, modulating IL-6 and IL-10 while not inhibiting the acute glucocorticoid response to a mild novel stressor in vivo. Journal of Functional Foods 2016, 27:42-54.

42. Kunishiro K, Tai A, Yamamoto I: Effects of rooibos tea extract on antigen-specific antibody production and cytokine generation in vitro and in vivo. Biosci Biotechnol Biochem 2001, 65:2137-2145.

43. Pantsi W, Marnewick J, Esterhuyse A, Rautenbach F, Van Rooyen J: Rooibos (Aspalathus linearis) offers cardiac protection against ischaemia/reperfusion in the isolated perfused rat heart. Phytomedicine 2011, 18:1220-1228.

44. Hendricks R, Pool EJ: The in vitro effects of rooibos and black tea on immune pathways. Journal of Immunoassay and Immunochemistry 2010, 31:169-180.

45. Lee W, Bae J: Anti-inflammatory Effects of Aspalathin and Nothofagin from Rooibos (Aspalathus linearis. Inflammation 2015, 38:1502-1516. 